\title{
PEMANFAATAN GULMA ECENG GONDOK SEBAGAI PENJERNIH AIR
}

\author{
Maria Christine Sutandi ${ }^{[1]}$, Alexander Genkensiana ${ }^{[2]}$, Cindy Claudia Ivany \\ Mayaut $^{[2]}$ \\ ${ }^{[1]}$ Dosen Program Studi S-1 Teknik Sipil, Universitas Kristen Maranatha \\ ${ }^{[2]}$ Mahasiswa Program Studi S-1 Teknik Sipil, Universitas Kristen Maranatha \\ Email: mrxtine@gmail.com, Nken822@gmail.com, cindyivanymayaut@gmail.com
}

\begin{abstract}
ABSTRAK
Indonesia merupakan sebuah negara berkembang yang beriklim tropis dengan curah hujan yang tidak menentu. Adakalanya hujan berlangsung terus menerus dan ada kalanya tidak ada hujan sama sekali dalam jangka waktu yang panjang. Sewaktu mengalami curah hujan yang panjang, seringkali terjadi banjir dan pastinya air banjir ini sangatlah kotor dan umumnya tidak dapat dipergunakan untuk MCK, dan sebagainya. Tujuan penelitian ini adalah membuat masyarakat yang ada pada lokasi banjir mendapatkan air bersih. Penelitian ini menggunakan metode coba-coba dengan melakukan percobaan di laboratorium, dengan menggunakan model. Pada penelitian penjernihan air ini kami menggunakan tanaman air yaitu eceng gondok dimana tanaman tersebut mempunyai keunggulan pada akarnya, seperti menjaga keseimbangan saat mengapung serta dapat menyerap polutan (logam) yang ada pada air sebagai makanannya dan menghasilkan oksigen yang diperlukan dalam proses aerasi sehingga terjadi koagulan. Dengan adanya penelitian ini dapat disimpulkan masyarakat yang terkena dampak banjir dan terisolasi masih dapat melakukan kegiatan sehariharinya dengan menggunakan air bersih dan diharapkan model ini dapat ditindaklanjuti dengan prototipe.
\end{abstract}

Kata kunci: Air Kotor, Banjir, Eceng Gondok, Penjernihan Air

\begin{abstract}
Indonesia is a developing country with a tropical climate with erratic rainfall. Sometimes it rains continuously and there are times when there is no rain at all over a long period of time. When experiencing long rainfall, there is often flooding and of course this flood water is very dirty and generally can not be used for MCK, and so on. The purpose of this research is to make the people at the flood site get clean water. This study uses a method of trial and error by conducting experiments in the laboratory, using models. In this water purification study we use water plants that are water hyacinth where the plant has advantages at the roots, such as maintaining balance when floating and can absorb pollutants (metals) in the water as food and produce the necessary oxygen in the aeration process so that coagulants occur. With this research can be concluded that people affected by floods and isolated can still do their daily activities using clean water and it is expected that this model can be followed up with prototypes.
\end{abstract}

Keywords: Dirty Water, Flooding, Water Hyacinth, Water Purification. 


\section{PENDAHULUAN}

\subsection{Latar Belakang}

Indonesia merupakan sebuah negara berkembang yang beriklim tropis dengan curah hujan yang tidak menentu, ada kalanya hujan berlangsung terus menerus dan panjang dan ada kalanya tidak ada hujan sama sekali dalam jangka waktu yang panjang. Sewaktu mengalami curah hujan yang panjang, seringkali terjadi banjir dan pastinya air disekitar perumahan menjadi sangatlah kotor dan umumnya tidak dapat dipergunakan untuk MCK. Pengolahan air baku yang bersih sangatlah dipentingkan saat banjir tiba dan di Indonesia diperkirakan akan mengalami krisis air bersih pada tahun 2025, air di kota Bandungpun dinyatakan dalam kondisi kritis, oleh karena itu diperlukan proses pemurnian air dengan metode yang effisien. (Ginardy, Maria, Fransiska 2010).

Apalagi jika pasokan air bersih terhenti dengan putusnya jaringan pipa air bersih, sedangkan sumur wargapun terendam air banjir, sehingga airnya tidak dapat dipergunakan. Bagaimana cara mengatasi kesulitan air bersih ini? Terpikirlah jika kolam ikan yang airnya keruh dan dengan adanya tumbuhan air, eceng gondok, ikan masih dapat hidup dengan nyaman dan dapat berkembang biak pula, maka dilakukanlah uji coba jika air banjir yang sangat kotor ini akan kita olah menjadi air bersih.

Tanaman air disebut demikian dikarenakan tanaman ini memang habitatnya di air dan biasanya lebih dikenal dengan tumbuhan hidrofit, yaitu tumbuhan yang menyesuaikan diri untuk hidup pada lingkungan perairan, baik terbenam sebagian maupun terbenam seluruh tubuhnya, sebagai contoh eceng gondok dan teratai terbenam sebagian tubuh tanamannya, sedangkan pakis air terbenam seluruh tubuh tanamannya.

Eceng gondok merupakan gulma, yaitu tumbuhan sebangsa rumput yang mengganggu bagi kehidupan tanaman utama, atau tumbuhan pengganggu, tidaklah salah jika gulma ini kita pakai dan kita gunakan sebagai salah satu elemen untuk menjernihkan air, karena akar dari eceng gondok ini dikenal dapat mengisap polutan yang ada di air, ini terbukti pada kolam yang banyak terdapat eceng gondok, habitat di dalamnya akan dapat hidup tenteram, dan airnya menjadi cukup jernih. (Rasyid 2017, Rukmi 2013, Ratnani 2011, Setyanto 2011).

\subsection{Perumusan Masalah/Identifikasi Masalah}

a. Dibuat model sederhana yang dapat dipergunakan sewaktu-waktu.

b. Pembatasan masalah, hanya sebatas air bersih. 
c. Parameter yang dianalisa hanya terbatas dari parameter fisik (Kejernihan, Warna dan bau).

\subsection{Tujuan, Manfaat dan metodologi Penelitian}

a. Tujuan penelitian ini adalah menjernihkan air banjir yang kotor dengan menggunakan gulma eceng gondok.

b. Manfaat penelitian ini sebagai model untuk dapat ditindaklanjuti dengan prototipe.

c. Adapun Metodologi penelitian yang akan dipakai pada penelitian ini adalah dengan cara mengadakan percobaan dengan berbagai jumlah eceng yang dipakai, ukuran ketebalan bahan penyaring dan waktu penelitian ditunjukkan Gambar 1.

\subsection{Kerangka Penelitian}

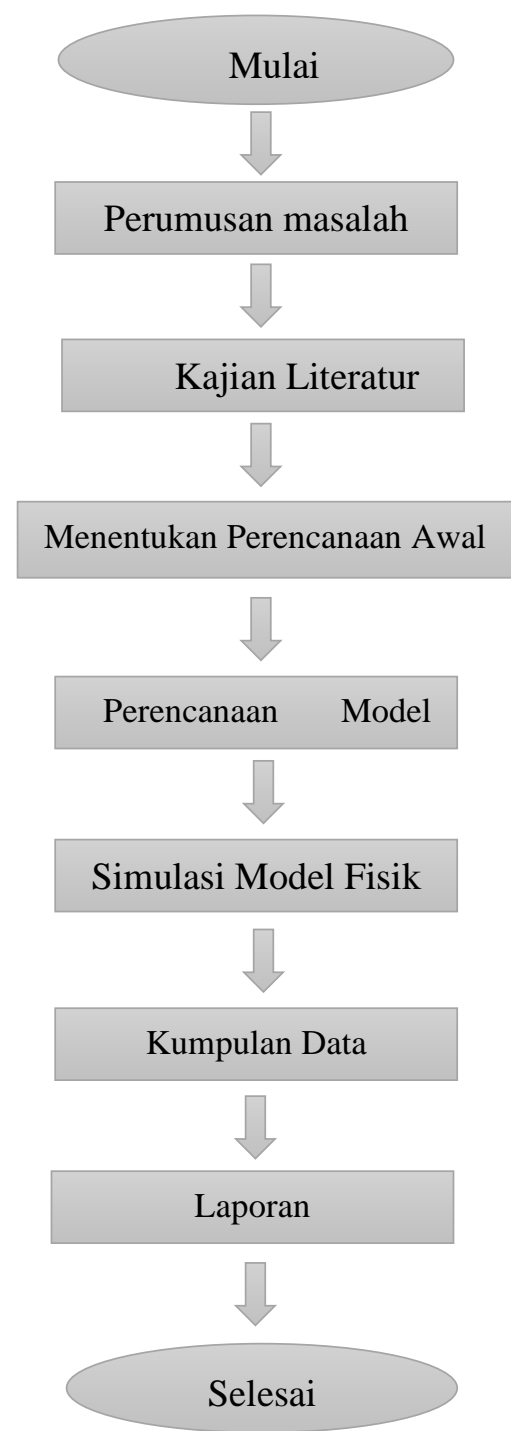

Gambar 1. Metodologi Penelitian 
Dalam kerangka penelitian ini akan dibahas mengenai serangkaian penelitian secara keseluruhan, yang dimulai dari hal-hal mengapa pada saat banjir banyak masyarakat yang sit untuk mendapatkan air bersih, kemudian diadakan pembatasan kondisi, dimana saat kondisi banjir sulit untuk mendapatkan bahan yang dinginkan, sehingga dapat dipastikan bahan mudah di dapatkan saat itu, yang dibahas pada perumusan masalah, sedangkan dalam kajian literatur dibahas tentang bahan utama, yaitu air dan tanaman eceng gondok nya sendiri, barulah dibuat model simulasi secara fisik dan dilakukan sesuai dengan kondisi di lapangan, setelah itu dilakukan pencatatan dan diakhiri dengan bentuk laporan, yang secara singkat dapat dilihat dalam bagan di atas.

\section{TINJAUAN PUSTAKA}

\subsection{Karakteristik Tanaman Air}

a. Pada salah satu sisi daun terjadilah peningkatan stomata.

b. Struktur batangnya kurang kaku.

c. Akarnya ringan dan tidak mendukung tanaman tersebut.

d. Karena akarnya berada dalam air, maka akar ini mengambil oksigen dari dalam air.

e. Kutikulanya tipis, karena tidak perlu mencegah kehilangan air.

f. Sel penjaga stomata umunya tidak aktif.

g. Umumnya mempunyai daun yang lebar dan tipis.

\subsection{Kajian Eceng Gondok}

Pada Gambar 2, terlihat gambar tanaman eceng gondok, yang umumnya hidup di rawa, tanah basah, cekungan yang berisi air dengan aliran yang lambat sampai tergenang, sungai dan umumnya merupakan gulma pada daerah tersebut.

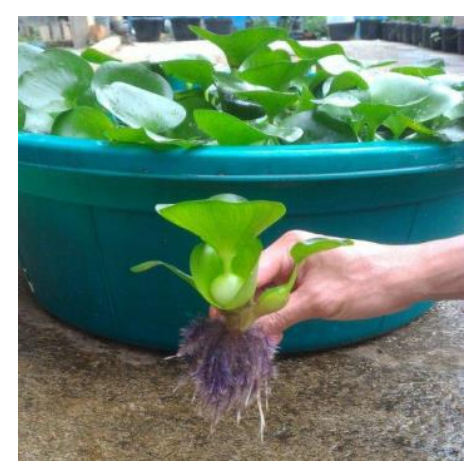

Gambar 2. Eceng gondok 
Tanaman eceng gondok ini akan berkembang dengan sangat cepat, pada musim penghujan dikarenakan pada saat musim penghujan air pada genangan akan mendapatkan banyak nutrisi, meskipun agak kotor, tetapi pada saat musim kemarau pun pertumbuhan eceng gondok ini cenderung akan bertambah panjang/tinggi/kurus. Yang sangat berperan dalam penjernihan air ini adalah peran dari akar eceng gondok, tak hanya bertugas sebagai menyerap zat-zat makanan dan unsur hara, eceng gondok juga memiliki akar serabut yang ditumbuhi bulu-bulu, bulu-bulu inilah yang berfungsi menjaga keseimbangan saat mengapung serta menjerat lumpur dan partikel-partikel yang terlarut dalam air, seperti terlihat pada Gambar 3. Gambar Akar Eceng Gondok. Selain itu jumlah tanaman eceng gondok juga sangat berperan dalam pengendalian air limbah (Dewi, Y.S 2012)

Meskipun tanaman eceng gondok ini sebagai gulma pada daerah tersebut, tetapi tanaman ini juga berkonstribusi sebagai penangkap polutan logam berat. Rangkaian penelitian ini pernah diteliti oleh Widyanto dan Susilo (1977) serta penelitian lanjutan oleh Lubis dan Sofyan (1986) melaporkan bahwa tanaman eceng gondok ini mampu menangkap beberapa polutan logam berat, seperti : Cd/Kadmium (1,35 mg/g), Merkuri/Hg (1,77 mg/g), Nikel (1,66 mg/g), serta Chrom/Cr serta penyerapan maksimal terjadi saat air berada pada PH 7 tak hanya polutan logam berat, eceng gondok mampu menangkap limbah hasil industri dan rumah tangga. (Rasyid, 2017, Rukmi 2013, Ratnani 2011, Setyanto 2011).

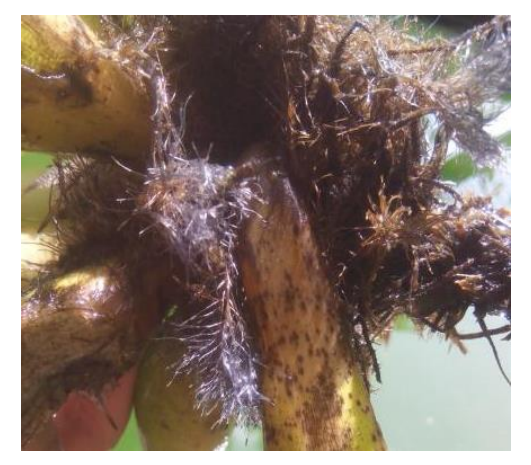

Gambar 3. Akar Eceng Gondok

\subsection{Kerugian dan Keuntungan Eceng Gondok}

Eceng gondok umumnya dianggap sebagai salah satu gulma yang sering kali meresahkan dikarenakan dapat meningkatkan penguapan yang cukup tinggi, juga sangat mengganggu lalu lintas air, serta bila eceng gondok ini mati dan tenggelam maka akan membuat pendangkalan pada daerah perairan tersebut. Namun dari sudut pandang yang lain eceng gondok dapat berguna dalam proses penjernihan air serta menyerap polutan 
logam berat serta dapat mengurangi beberapa penyakit yang disebabkan oleh banjir karena dapat menyerap amonia yang berlebihan pada air kotor yang melibatkan akar serabut, akar serabut inilah yang berfungsi menjerat lumpur dan partikel-partikel logam yang terlarut dalam air dan menurunkantingkat kelarutan oksigen. diakses pada tanggal (14 Juni 2019).

\subsection{Bak Penelitian}

Bak ini diperlukan untuk penelitian dengan merubah ketebalan dan banyaknya jumlah lapisan penyaring, terlihat pada Gambar 4 rangkaian bak penyeringan rencana.

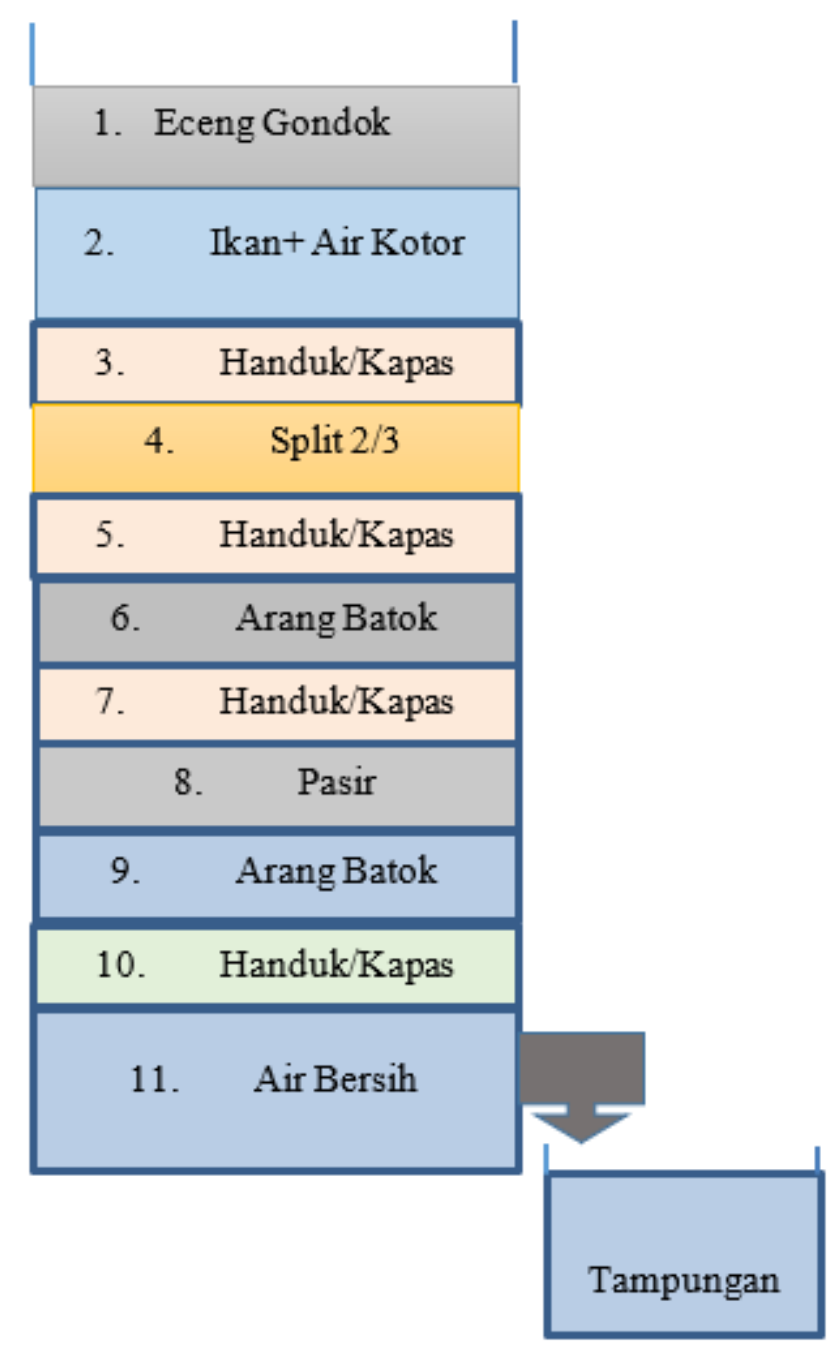

Gambar 4. Rangkaian Bak Penyaringan Rencana

Bak Penelitian yang kami rencanakan tidak menggunakan lapisan 3, 5, dan 7, dikarenakan kami menginginkan model yang senatural mungkin sehingga objek penelitian 
(Ikan) dapat hidup sesuai dengan alamnya sehingga kami membuatnya seperti Gambar 5. Rangkaian bak penyaringan model di bawah ini.

\subsection{Langkah Penelitian}

1. Perakitan model penyaringan seperti gambar terlampir dalam lampiran.

2. Isi model dengan air selama 2 minggu, umtuk menetralisir bau dari lem yang di pergunakan.

3. Menguras model hingga bersih kembali.

4. Lakukan kembali langkah nomor 2 dan nomor 3, sampai bau hilang.

5. Model dikeringkan dan disusun sesuai dengan komponen yang di rencanakan seperti Gambar 4 rangkaian bak penyaringan model.

6. Isi model dengan air dan di diamkan selama 1 minggu.

7. Keluarkan air seluruh air yang ada di dalam model.

8. Isi kembali model dengan air kotor dan ditambahkan eceng gondok.

9. Diamkan kondisi nomor 8 selama 1 minggu.

10.Masukkan ikan kedalam model sebagai objek penguji oksigen yang di perlukanJika ikan mati maka air tidak layak untuk mahkluk hidup. Begitupun sebaliknya.

11.Kurangi air dengan mengeluarkan sebagian dari model dan menambahkan kembali air kotor.

12.Diamkan kondisi tersebut selama seminggu.

13.Untuk mengecek apakah air sudah jernih, buka kran dan tampung air tersebut dalam gelas kramik. Bila air tersebut masih keruh maka kita lakukan kembali langkah nomor 11. Lakukan langkah tersebut hingga air menjadi jernih.

14.Kondisi air sudah mencapai keseimbangan kejernihan.

15.Jika air hasil tampungan dibiarkan lebih lama maka akan menimbulkan bau tak sedap yang menyengat, ini akan menjadi penelitian kami di tahap selanjutnya.

16.Jika air berbau tak sedap, kami mencoba untuk mengalirkan air percobaan. 


\subsection{Kegunaan Komponen Penelitian}
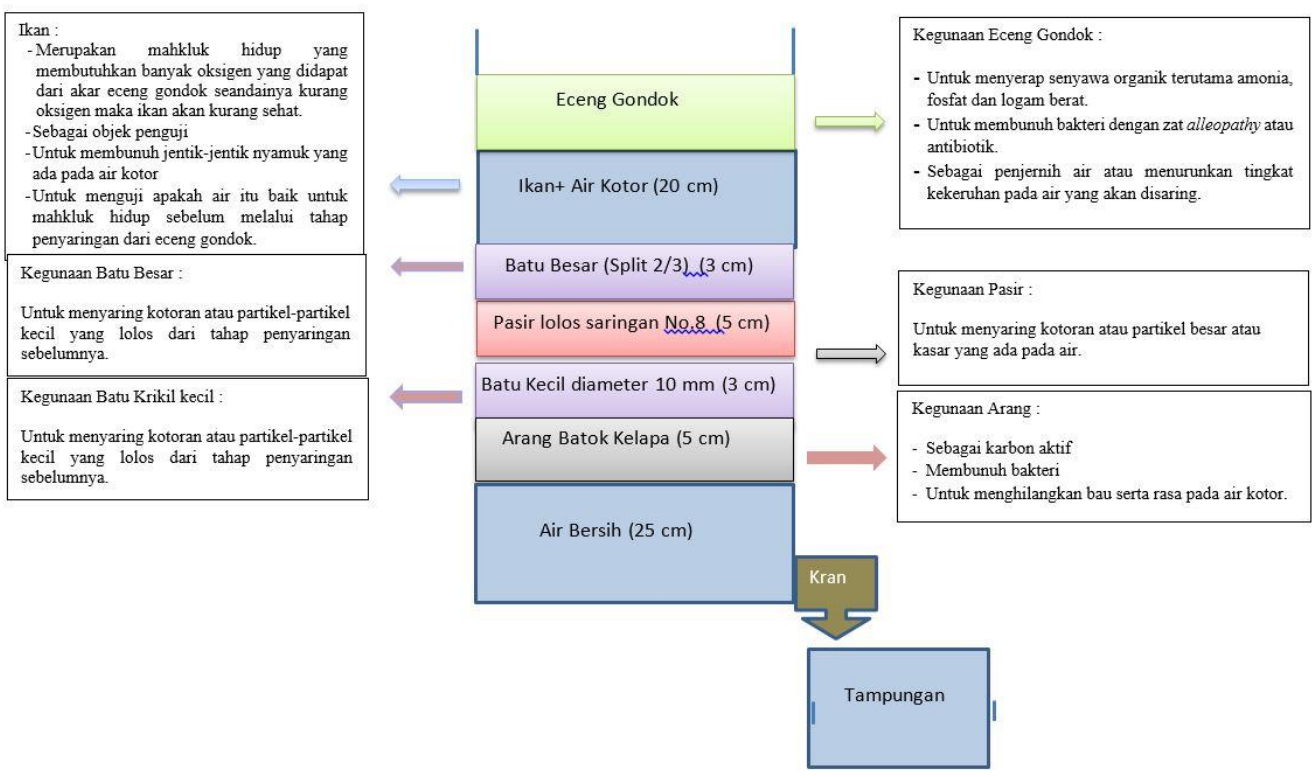

Gambar 5. Rangkaian Model Bak Penyaringan

\section{DATA DAN ANALISIS PENELITIAN}

\subsection{Jadwal Penelitian Awal/Pendahuluan}

Tabel 1 Jadwal Penelitian Awal

\begin{tabular}{lllll}
\hline No. & Tanggal & Keterangan \\
\hline 1. & 05 Februari 2019 & & \\
\hline
\end{tabular}




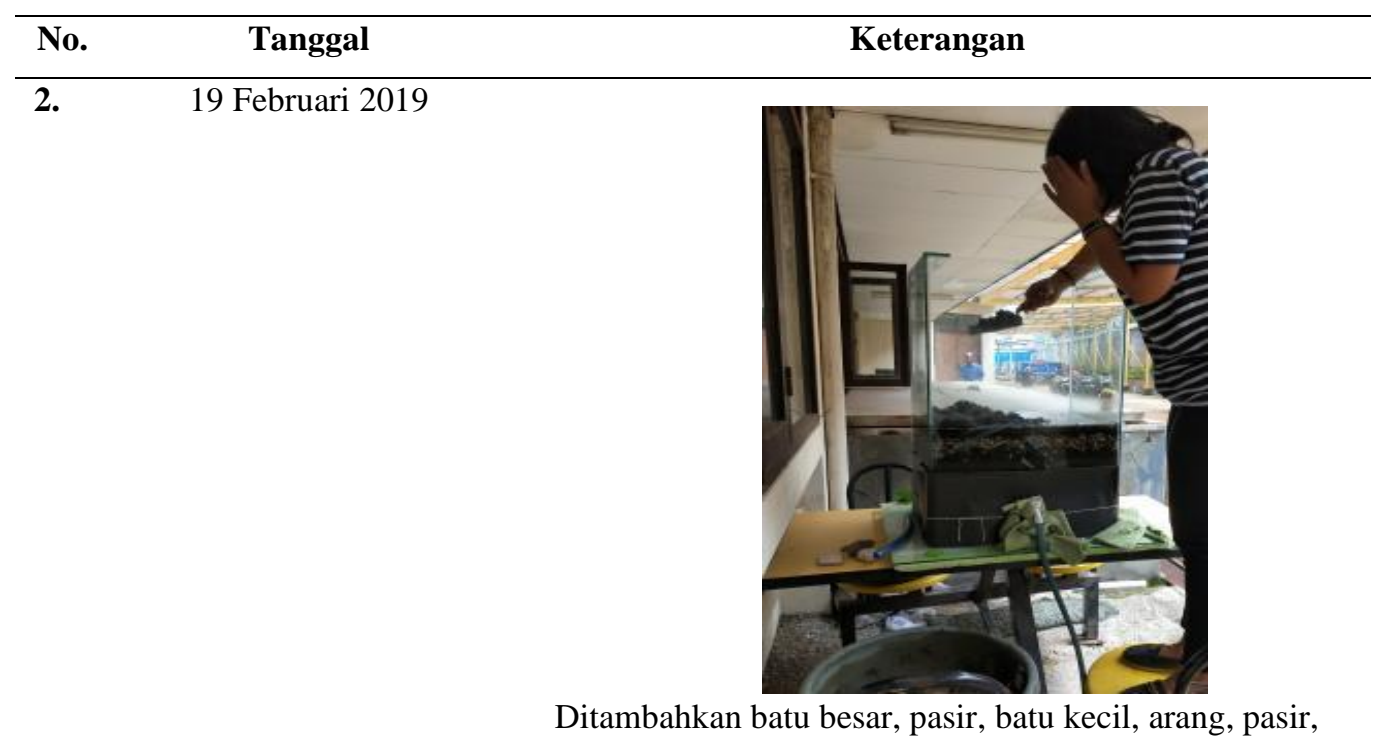
dan air kotor kedalam model.

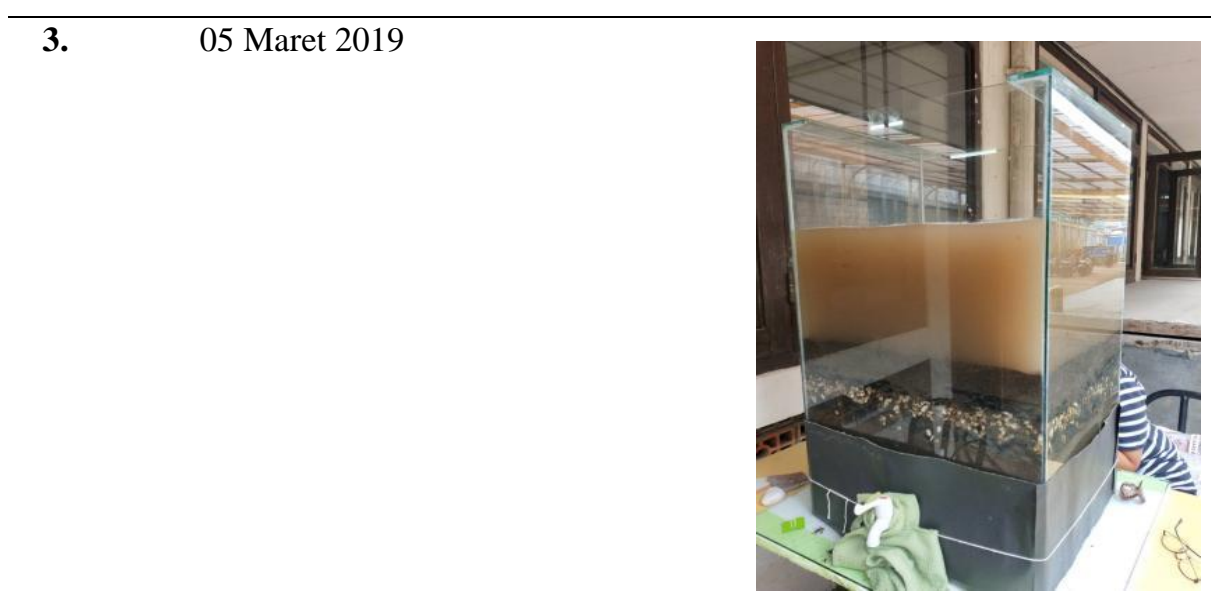

Masukkan air keruh kedalam model dan mengurangi air dengan mengeluarkan sebagian air dari model melalui kran dan menambahkan kembali air kotor.

4. 26 Maret 2019

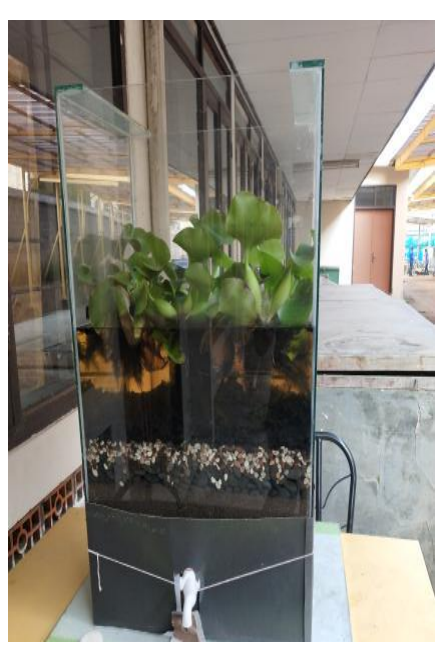

Model lengkap dengan ekosistemnya 


\begin{tabular}{ccc}
\hline No. & Tanggal & Keterangan \\
\hline 5. & 02 April 2019 & \\
& & Mengecek air apakah sudah jernih atau belum.
\end{tabular}

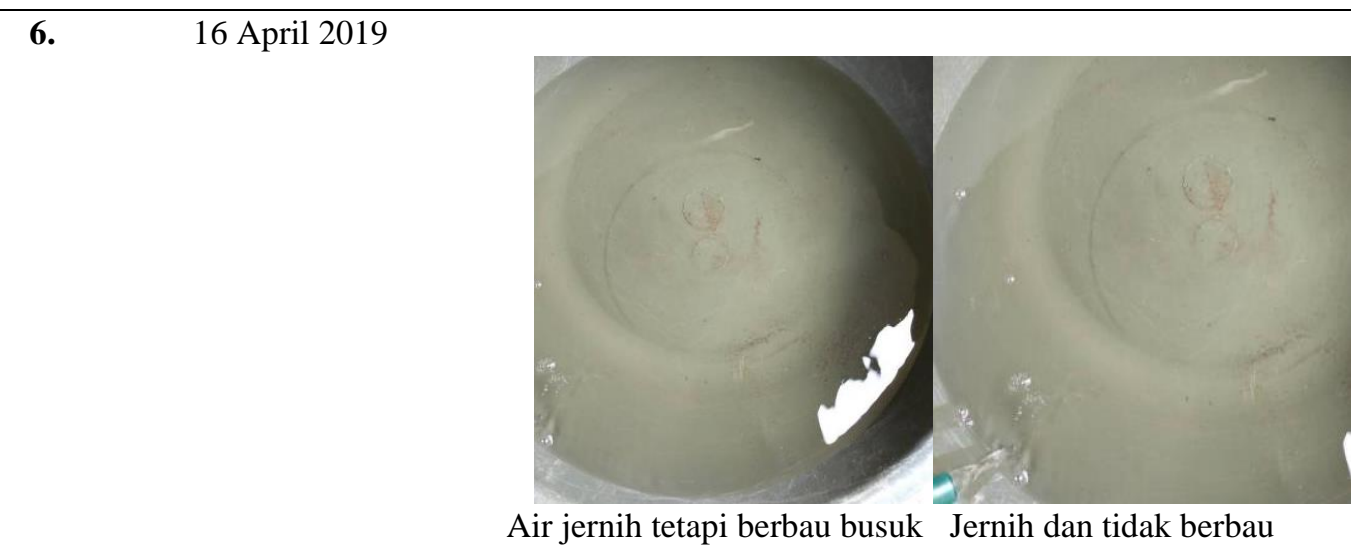

7. 30 April 2019

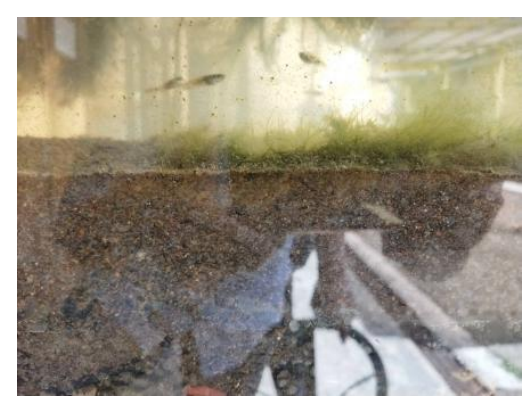

Muncul koagulan diatas pasir lapisan pertama, dan ikan tetap hidup

\subsection{Simulasi Model Fisik dan Data Pengamatan}

Komposisi dan urutan lapisan penyaringan sederhana dapat dilihat pada Tabel 1. Tabel Pengamatan Percobaan, komposisi bahan tetap, tetapi jumlah bahan di simulasikan, sedangkan jumlah eceng disimulasikan juga serta simulasi pada cara pengerjaan percobaan, sampai di dapatkan hasil yang diinginkan:

a. PERCOBAAN A

Lama percobaan selama 1 minggu dan air tidak dialirkan, hanya di dalam bak penampungaan yang berisi air kotor berserta 5 ekor ikan dan 3 pohon eceng 
gondok, hasilnya ikan ada yang mati, daun pohon eceng menguning daunnya dan air tetap keruh dan sangat berbau.

b. PERCOBAAN AA

Lama percobaan selama 2 minggu dan air tidak dialirkan, hanya di dalam bak penampungaan yang berisi air kotor berserta 5 ekor ikan dan 3 pohon eceng gondok, hasilnya ikan mati semua, daun pohon eceng makin menguning, lebih menguning dari percobaan $\mathrm{A}$, air tetap keruh dan masih sangat berbau, malah lebih bau.

c. PERCOBAAN B

Lama percobaan selama 1 minggu dan air dialirkan berselang sehari, artinya 1 hari air dialirkan dan 1 hari kemudian air tidak dialirkan, bak tetap diisi dengan 5 ekor ikan, dan eceng 5 pohon, artinya pohon eceng kami tambah jumlahnya, mulailah terjadilah perubahan, ikan tidak ada yang mati, juga daun pohon eceng tetap berwarna hujau, walaupun agak pucat, kekeruhan air agak berkurang, tetapi tetap keruh dan masih sangat berbau.

\section{d. PERCOBAAN BB}

Lama percobaan selama 2 minggu dan air dialirkan berselang 2 hari, artinya 2 hari air dialirkan dan 2 hari air tidak dialirkan, bak tetap diisi dengan 5 ekor ikan, dan eceng tetap 5 pohon, ada sedikit perubahan, ikan tidak ada yang mati, juga daun pohon eceng lebih segar walaupun masih agak pucat, kekeruhan air agak berkurang, dan masih sangat berbau.

e. PERCOBAAN C

Lama percobaan selama 1 minggu dan air dialirkan menerus, bak tetap diisi dengan 5 ekor ikan, dan eceng 6 pohon, pohon eceng kami tambah 1, terjadilah perubahan, ikan tidak ada yang mati, bahkan ikan beranak, terlihat dengan adanya ikan kecil2, juga daun pohon eceng tetap berwarna hujau, walaupun masih agak pucat, kekeruhan air menjadi lebih jernih dari semula, tetapi masih ada bau, artinya bau berkurang dari percobaan sebelumnya.

f. PERCOBAAN CC

Lama percobaan selama 2 minggu dan air dialirkan menerus, bak tetap diisi dengan 5 ekor ikan, dan eceng 6 pohon, pohon eceng kami tambah 1, terjadilah perubahan, ikan sudah tidak ada yang mati, bahkan ikan beranak lebih banyak, terlihat dengan adanya ikan kecil2, juga daun pohon eceng tetap berwarna hujau, masih agak pucat 
tetapi lebih segar, kekeruhan air menjadi jernih, tetapi masih berbau, artinya bau berkurang dari percobaan sebelumnya.

\section{g. PERCOBAAN D}

Lama percobaan selama 1 minggu dan air dialirkan menerus, bak tetap diisi dengan 5 ekor ikan, dan eceng 7 pohon, pohon eceng kami tambah 1dari percobaan sebelumnya (percobaan C), terjadilah perubahan, ikan berkembang biak lebih banyak terlihat dengan adanya lebih banyak ikan kecil2, pohon ecengnya berkembang juga, dengan terlihat adanya sulur-sulur baru (2 buah sulur), sedangkan air menjadi jernih, dan sudah tidak berbau.

h. PERCOBAAN DD

Lama percobaan selama 2 minggu dan air dialirkan menerus, bak tetap diisi dengan 5 ekor ikan, dan eceng tetap 7 pohon, terjadilah perubahan lebih baik, ikan berkembang biak lebih banyak terlihat dengan adanya lebih banyak ikan kecil2, pohon ecengnya berkembang juga, dengan terlihat adanya sulur2 baru (4 buah sulur baru), sedangkan air menjadi jernih, dan sudah tidak berbau.

\section{i. PERCOBAAN E}

Lama percobaan selama 1 minggu dan air dialirkan menerus, bak tetap diisi dengan 5 ekor ikan, dan eceng 8 pohon, pohon eceng kami tambah 1 dari percobaan sebelumnya (percobaan D), terjadilah perubahan, ikan berkembang biak lebih cepat terlihat dengan adanya lebih banyak ikan kecil2, pohon ecengnya berkembang juga, dengan terlihat adanya sulur2 baru ( 3 sulur baru), menjadi 11 pohon, sedangkan air menjadi jernih sekali, dan sudah tidak berbau.

\section{j. PERCOBAAN EE}

Lama percobaan selama 2 minggu dan air dialirkan menerus, bak tetap diisi dengan 5 ekor ikan, dan eceng 8 pohon, pertumbuhan pohon eceng kami tambah lebih cepat, dari 8 phon menjadi 16 pohon dan juga mulai keluar kuncup bunga, ikan juga berkembang biak lebih cepat terlihat dengan adanya lebih banyak ikan kecil2, sedangkan air menjadi jernih sekali, dan sudah tidak berbau.

Untuk lebih jelasn dan singkat Data dan Analisis Percobaan dibuat dalam bentuk tabel, dan dapat disajikan pada Tabel 2. 
Tabel 2. Tabel Percobaan

\begin{tabular}{|c|c|c|c|c|c|c|c|c|c|c|}
\hline \multirow{2}{*}{ Bahan } & \multicolumn{10}{|c|}{ PERCOBAAN } \\
\hline & $\mathbf{A}$ & $\mathbf{A A}$ & B & BB & $\mathbf{C}$ & $\mathrm{CC}$ & D & DD & $\mathbf{E}$ & EE \\
\hline $\begin{array}{c}\text { Waktu } \\
\text { pengerjaan } \\
\text { (minggu) }\end{array}$ & 1 & 2 & 1 & 2 & 1 & 2 & 1 & 2 & 1 & 2 \\
\hline $\begin{array}{l}\text { Waktu } \\
\text { pengaliran } \\
\text { (minggu) }\end{array}$ & diam & diam & $1-1$ & $2-2$ & terus & terus & terus & terus & terus & terus \\
\hline Eceng (Pohon) & 3 & 3 & 5 & 5 & 6 & 6 & $7-9$ & $7-11$ & $8-11$ & $8-16$ \\
\hline Ikan (Ekor) & $5-3$ & $5-0$ & $5-5$ & $5-5$ & 5-anak & 5-anak & 5-anak & 5-anak & 5-anak & 5-anak \\
\hline $\begin{array}{c}\text { Air kotor dan } \\
\text { keruh }\end{array}$ & 20 & 20 & 20 & 20 & 20 & 20 & 20 & 20 & 20 & 20 \\
\hline $\begin{array}{l}\text { Arang Batok } \\
\text { Kepala }(\mathrm{cm})\end{array}$ & 3 & 4 & 4 & 5 & 5 & 5 & 6 & 6 & 6 & 6 \\
\hline $\begin{array}{l}\text { Pasir \# No. } 8 \\
(\mathrm{~cm})\end{array}$ & 4 & 4 & 4 & 4 & 4 & 4 & 4 & 4 & 4 & 4 \\
\hline $\begin{array}{l}\text { Batu diameter } \\
\qquad 10 \mathrm{~mm}\end{array}$ & 3 & 3 & 4 & 4 & 4 & 4 & 4 & 4 & 4 & 4 \\
\hline $\begin{array}{c}\text { Pasir \# No } 8 \\
{[\mathrm{~cm}]}\end{array}$ & 5 & 5 & 6 & 6 & 7 & 7 & 8 & 8 & 8 & 8 \\
\hline Split 2/3 [cm] & 5 & 5 & 5 & 5 & 5 & 5 & 5 & 5 & 5 & 5 \\
\hline Air Jernih & 25 & 25 & 25 & 25 & 25 & 25 & 25 & 25 & 25 & 25 \\
\hline Kejernihan & keruh & keruh & $\mathrm{AG}$ & $\mathrm{AG}$ & Jernih & Jernih & Jernih & Jernih & JS & $\mathrm{JS}$ \\
\hline Kebauan & $\mathrm{BB}$ & $\mathrm{BB}$ & $\mathrm{BB}$ & $\mathrm{B}$ & $\mathrm{B}$ & $\mathrm{B}$ & $\mathrm{TB}$ & TB & TB & TB \\
\hline
\end{tabular}

Keterangan:

\begin{tabular}{ccccc}
\hline Percobaan & Kejernihan & Catatan & Kebauan & Catatan \\
\hline A & Keruh & Makin & Bau Busuk [BB] & Makin \\
AA & Keruh & & Bau Busuk [BB] & \\
B & Agak Keruh $[\mathrm{AG}]$ & & Bau Busuk [BB] & \\
BB & Agak Keruh $[\mathrm{AG}]$ & kebawah & Bau Busuk [BB] & kebawah \\
C & Agak Keruh $[\mathrm{AG}]$ & & Bau [B] & \\
CC & Agak Keruh $[\mathrm{AG}]$ & & Bau [B] & \\
D & Jernih & makin & Tidak Bau [TB] & makin \\
DD & Jernih & & Tidak Bau [TB] & \\
E & Jernih & jernih & Tidak Bau [TB] & tidak berbau \\
EE & Jernih Sekali [JS] & & Tidak Bau [TB] & \\
\hline
\end{tabular}




\section{KESIMPULAN}

Dari hasil penelitian menunjukkan bahwa gulma eceng gondok yang semula sangat mengganggu, dapat dimanfaatkan untuk menjernihkan air kotor, air yang berbau tak sedap, sehingga air yang pada awalnya keruh dan berbau tak sedap dapat digunakan setidaknya untuk MCK pada saat terjadinya bencana banjir.

Dari percobaan terlihat bahwa $0,2 \times 0,5 \times 0,8=0.08 \mathrm{~m}^{3}$ setara dengan $80 \mathrm{lt}$ air kotor sudah cukup menggunakan 8 pohon eceng gondok untuk dapat menjernihkan air kotor dan berbau tak sedap, juga ikan dapat berkembang biak, dengan perkataan lain air tersebut sudah ramah lingkungan. Semakin banyak jumlah eceng gondok semakin baik kwalitas airnya, terlihat dari banyak nya ikan yang berkembang biak dan air semakin jernih, tetapi sangatlah disarankan untuk penelitian lebih lanjut, diadakan pengujian pada laboratorium.

\section{DAFTAR PUSTAKA}

1. Dewi, Y. S. 2012. Efektivitas Jumlah Rumpun Tanaman Enceng Gondok (Eichhornia crassipes (Mart.) Solm) dalam Pengendalian Limbah Cair Domestik. Jurnal Teknik Lingkungan. 2 (13): 151-158.

2. Ginardy Husada, Maria Christine,Maria Fransiska 2010 Kajian Kelayakan Air Sungai Cikapundung Sebagai Air Bersih. Jurnal Teknis Sipil Vol 6 No2.

3. Rasyid dan, F. 2017. Pemanfaatan Tumbuhan Air untuk Mereduksi Limbah Logam Timbal $(\mathrm{Pb})$ dan Besi $(\mathrm{Fe})$ dengan Model Reaktor Constant Head Tipe Filtrasi. Sensistek. 14 (2): 10-19.

4. Rukmi, D.P., Ulyke., dan Pujiati, R.S. 2013. Efektifitas Eceng Gondok (Eichhornia crassipes) dalam Menurunkan Kadar Deterjen, BOD, dan COD pada Air Limbah Laundry (Study di Laundry X di Kelurahan Jember Kecamatan Patrang Kabupaten Jember). Ikesma. 9 (1): 12-19.

5. Ratnani, D.R. 2011 Pemanfaatan Eceng Gondok (Eichornia Crassipes) Untuk Menurunkan Kandungan COD,Warna Pada Limbah Cair Tahu. Universitas Wahid Hasyim. Semarang. Jurnal Teknik Kimia, Vol 7 No 1, 41-47.

6. Julita, O.V. 2018. Pemanfaatan Eceng Gondok untuk Mengurangi Kadar Zat Kimia Limbah Laundry. p. 1-4.

7. Amin dan Mustafa, 2000. Kualitas Air Danau Tempe Pada Saat Naik dan Surut. Prosidding, Semiloka Nasional dan Pemanfaatan Danau dan Waduk. Jurusan Perikanan Fakultas Pertanian Universitas Padjajaran. Bandung. 
8. Ratnani, dkk 2011. Pemanfaatan Eceng Gondok (Eichornia Crassipes) Untuk Menurunkan Kandungan COD,Warna Pada Limbah Cair Tahu. Universitas Wahid Hasyim. Semarang. Jurnal Teknik Kimia, Vol 7 No 1 April 2011.

9. Setyanto, dkk 2011. Pemanfaatan Enceng Gondok Untuk Membersihkan Kualitas Air Sungai Sungai Gajahwong Yogyakarta. Jurnal teknologi Vol. 4 No. 1 Agustus 2011, ISSN 1979-8415.

10. Hidayat, dkk 2011. Efektifitas Tanaman Enceng Gondok (Eichornia crassipes) Dalam Penurunan Kadar Besi Fe Pada Leachate. Jurnal Fakultas Kesehatan Masyarakat. Universitas Muhammadiyah Semarang. 